\begin{tabular}{llllll} 
& ISRA (India) $=\mathbf{3 . 1 1 7}$ & SIS (USA) $=\mathbf{0 . 9 1 2}$ & ICV (Poland) & $\mathbf{= 6 . 6 3 0}$ \\
Impact Factor: & ISI (Dubai, UAE) $=\mathbf{0 . 8 2 9}$ & PUHЦ (Russia) $=\mathbf{0 . 1 5 6}$ & PIF (India) & $=\mathbf{1 . 9 4 0}$ \\
& GIF (Australia) $=\mathbf{0 . 5 6 4}$ & ESJI (KZ) & $\mathbf{8 . 7 1 6}$ & IBI (India) & $=\mathbf{4 . 2 6 0}$ \\
& JIF & $\mathbf{1 . 5 0 0}$ & SJIF (Morocco) $=\mathbf{5 . 6 6 7}$ & OAJI (USA) & $\mathbf{0 . 3 5 0}$ \\
\hline
\end{tabular}

\section{SOI: $\underline{1.1 / \mathrm{TAS}}$ DOI: $10.15863 / \mathrm{TAS}$ International Scientific Journal Theoretical \& Applied Science}

\author{
p-ISSN: 2308-4944 (print) e-ISSN: 2409-0085 (online) \\ Year: $2019 \quad$ Issue: $06 \quad$ Volume: 74
}

Published: $13.06 .2019 \quad$ http://T-Science.org
QR - Issue

QR - Article
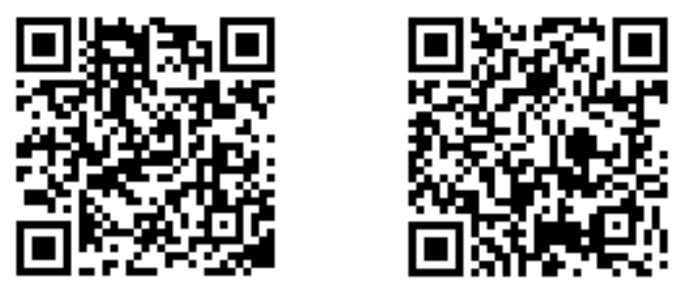

Norberto M. Secretaria

Cebu Technological University

A.B., M.B.A, PH.D.

Social Sciences and Management Department College of Arts and Sciences, Cebu, Philippines

(0938-224-3169)

norbertosecretaria@gmail.com

\title{
THE E-COMMERCE REVOLUTION: STATUS, AWARENESS AND DEMOGRAPHICS OF FARMERS IN CEBU CITY
}

\begin{abstract}
The advent of e-commerce have been so remarkable that it changes the face of modern business. This study presents the current status of e-commerce in the Philippines, as well as the demographic profiles of the smallscale farmers through survey method, in order to determine whether or not there is awareness among small-scale farmers on the available e-commerce and social media platform. The data revealed that, e-commerce in the Philippines is a promising industry with a significant share in the Gross Domestic Product. Though the same is true, enumerable factors continue to challenge its growth such as, political stability, natural disasters, technology availability, technology awareness and the perennial problem of poverty. Additionally, the data revealed that the small-scale farmers have very slight awareness on the current available e-commerce and social media platforms in the Philippines. Though there is found to have significant correlation between Age, Years in Farming and Income, the data finally revealed that there was no significant correlation between the level of awareness and the respondents' income. The data simply means that in the present status of e-commerce in the Philippines, huge effort still has to be exerted that the promise of e-commerce as a more efficient business platform, will penetrate the very root of the Philippine economy, the farmers.

Key words: e-Commerce, Social Media, Technology Awareness, Farmers, Poverty.

Language: English

Citation: Secretaria, N. M. (2019). The e-commerce revolution: status, awareness and demographics of farmers in Cebu city. ISJ Theoretical \& Applied Science, 06 (74), 101-109.

Soi: http://s-o-i.org/1.1/TAS-06-74-7 Doi: crossef https://dx.doi.org/10.15863/TAS.2019.06.74.7
\end{abstract}

\section{INTRODUCTION}

Technology is an indispensable element of the modern society. It fuels the economy. Technology pierces through different fields and revolutionized the same. In this era of the $4^{\text {th }}$ Industrial Revolution[1], [2], sales management was no longer spared by technological advancement. When the World Wide Web was developed by Tim Berners Lee, the world was restructured into a whole new face. People begun to communicate with stunning speed like never before. It was so revolutionary, that distance was no longer a barrier for delivering and receiving message. With this development, the world's economy begun to grow enormously, people communicate so easily from all corners of the globe, products are produced at lightning speed. With the advent of smart phones, people are easily connected with just a tap of the fingertips. Commerce is transformed to fit in a device in every person's palms.

E-commerce was made possible when the internet was introduce for commercialization in 1991. Since then, e-commerce have a tremendous positive impact on success of a business venture [3], [4] Word of mouth in the electronic form is also a very powerful marketing tool [5]. Several studies published the positive inclination of electronic marketing towards business success [3], [5]-[7]. Additional studies provided that internet marketing plays a very important role in the success of a business [8]-[10].

On the other long arm of the story, while industry flourished, industrial goods available in the internet, farmers in the Philippines remained in the dark corners of traditional buy and sell. They remain to be the poorest sector in the Philippines[11]. This, noting 


\begin{tabular}{llllll} 
& ISRA (India) $=\mathbf{3 . 1 1 7}$ & SIS (USA) $=\mathbf{0 . 9 1 2}$ & ICV (Poland) & $\mathbf{= 6 . 6 3 0}$ \\
Impact Factor: & ISI (Dubai, UAE) $=\mathbf{0 . 8 2 9}$ & PUHЦ (Russia) $=\mathbf{0 . 1 5 6}$ & PIF (India) & $=\mathbf{1 . 9 4 0}$ \\
& GIF (Australia) $=\mathbf{0 . 5 6 4}$ & ESJI (KZ) & $\mathbf{8 . 7 1 6}$ & IBI (India) & $=\mathbf{4 . 2 6 0}$ \\
& JIF & $\mathbf{1 . 5 0 0}$ & SJIF (Morocco) $=\mathbf{5 . 6 6 7}$ & OAJI (USA) & $\mathbf{0 . 3 5 0}$ \\
\hline
\end{tabular}

that farmers, in all of history are indispensable element of the human society. They serve to be the most significant part of human development. What people eat and drink are proud produce of a laboring farmer somewhere around the globe. As one enjoys every party, celebrations, or simply bumping into a drive through fast food chain, a farmer made it possible with their own sweat.

It should be noted however that the focus of this paper are small scale farmers, with land area less than one hectare of land cultivation[12]. Industrial farms can afford heavy advertising and aggressive marketing but small scales cannot. Small-scale farmers, especially in the Philippines can in no way compete with industrial farms in terms of advertising and marketing in the traditional mediums. The rate is just so high. For instance, in the national scale advertising on television can cost up to $\mathrm{Php}$ $800,000.00$ or $\$ 14,000.00$ per 30 seconds of air-time. Thanks to the cheap and modern way of advertising medium, the small scale farmers can now compete with the industrial farms. This is where the ecommerce, in theoretical sense, plays a very important role.

Farmers, through available platforms can explore the wide horizon of the internet through electronic commerce, so they can sell farm produce right on the palm of their hands. This notion should have been the ideal sense but boils down to the questions of whether or not farmers know or even aware that these platforms are available. China and India have be in route to e-commerce in agriculture[13], [14]. Or simply, whether or not farmers do know how to make use of these platforms should they happen to know the said technology. Added to the fact that farmers are ageing. What could be its implication to the level of awareness as well? These things mentioned are mere possible factors and indicators that may fill the gray area of understanding regarding this matter. With all the studies available in the fields of research, very seldom a study can be found focusing on the awareness of farmers in the modern method of selling farm produce.

This paper will present the current status of ecommerce in the Philippines, the awareness on ecommerce and social media technology, as well as demographics among small scale farmers. Finally, to show whether or not there is a correlation between demographic variables, awareness to income, and in the attempt to fill the gap, as to whether or not, this explosion of e-commerce in the Philippines poses considerable impact to small scale farmers.

\section{METHODOLOGY}

This paper utilized descriptive correlational method. The data was gathered through a survey method. There were a total of 156 respondents in this study. The respondents were selected through multistage random sampling from the 52 local farmers' organizations from the mountain villages of Cebu City, Philippines. The data gathered was treated, analyzed and interpreted. In the analysis of the data, statistical software were used. Secondary data were also utilized to present the status of e-commerce in the Philippines.

\section{RESULTS AND DISCUSSIONS}

This portion of the paper presents the data gathered in this research, together with its interpretation, analysis and discussions. Secondary data presented therein are sourced from reputable institution which are respectfully cited.

\section{Ecommerce in the Philippines}

We Are Social, published in 2018 that internet users passes the 4 Billion mark. This simply means that the world is rapidly interconnected, and ecommerce will become the controlling industry for sales and marketing.

With the unquestionable rise in the world's connectivity, The Philippines wishes to take a bigger share of the pie and the glory that goes with it. Philippines is an archipelagic country dubbed to be one of the fastest growing economy in the world[15]. Its populations have been growing at $1.72 \%$ annually, reaching at 100.98 Millions in Philippines Statistics Authority official census of 2015. The Philippines is one of fastest growing internet population in the world, according to statistical calculations published by the Department of Trade and Industries Philippines, the annual growth of internet users in the Philippines in the past five years reached as high as $530 \%$, Indonesia at $430 \%$ and India at $230 \%$ [16]

In the past years, ecommerce in the Philippines have been very promising. The Philippine ecommerce industry is at US\$1.15 Billion and it is to rise at $104 \%$ from 2013-2018[17]. Considering the relatively youth populace in the social media and the internet, it would be expected that the growth of this industry will be exponential.

An amazing truth about the Philippine digital economy is that, the total subscription exceeds the total population. There are a total of 121.4 Million mobile subscription in the Philippines, against the total population 105 Million in real time counting. That is simply $115 \%$ of the total population [18], [19]

In support to the progress of ecommerce in the Philippines, the Philippine congress of both houses, the senate and the House of Representatives passed several measures in order to promote and regulate the ecommerce business and the use of the 


\begin{tabular}{llllll} 
& ISRA (India) $=\mathbf{3 . 1 1 7}$ & SIS (USA) $=\mathbf{0 . 9 1 2}$ & ICV (Poland) & $\mathbf{= 6 . 6 3 0}$ \\
Impact Factor: & ISI (Dubai, UAE) $=\mathbf{0 . 8 2 9}$ & PUHЦ (Russia) $=\mathbf{0 . 1 5 6}$ & PIF (India) & $=\mathbf{1 . 9 4 0}$ \\
& GIF (Australia) $=\mathbf{0 . 5 6 4}$ & ESJI (KZ) & $\mathbf{8 . 7 1 6}$ & IBI (India) & $=\mathbf{4 . 2 6 0}$ \\
& JIF & $\mathbf{1 . 5 0 0}$ & SJIF (Morocco) $=\mathbf{5 . 6 6 7}$ & OAJI (USA) & $\mathbf{0 . 3 5 0}$ \\
\hline
\end{tabular}

internet. Republic Act 8792, or The Electronic Commerce Act (ECA) aims to facilitate domestic and international dealings, transactions, arrangements agreements, contracts and exchanges and storage of information through the utilization of electronic, optical and similar medium, mode, instrumentality and technology to recognize the authenticity and reliability of electronic documents related to such activities and to promote the universal use of electronic transaction in the government and general public (Sec 3, RA 8792). The Cybercrime Prevention Act of 2010, Republic Act 10175 provides protection of internet users including the ecommerce industry from exploits of the evil doers (Sec. 1., R.A. 10175). The Ecommerce Act or Access Device Regulation Act, Republic Act 8484 which specifies that the State shall protect the rights and define the liabilities of parties in such commercial transactions by regulating the issuance and use of access devices (Sec 2, RA 8484). On 20 October 2008, The Philippine Government through the Department of Trade and Industry, Department of Health, and Department of Agriculture produced a joint memorandum in order to protect the ecommerce users. (DTI-DOH-DA Joint Administrative Order (AO) No. 1 - "Rules and Regulations for Consumer Protection in a Transaction Covered by the Consumer Act of the Philippines (R.A. 7394) through Electronic Means under the Ecommerce Act (R.A. 8792)" or the E-Consumer Protection Guidelines).

Further development ensued to protect online users and the ecommerce buyers through Republic Act No. 10173 or the Data Privacy Law was enacted in 2012 with the intention of protecting personal information (including sensitive personal information) of Filipinos. In similar line, taxes are now filed and paid through electronic means. Electronic systems flourished, E-banking, E-payment and the Government Implements the National WiFi System with a budget of 1.4 Billion Pesos [21]. This introduction of new technology in public places as well as state colleges and universities found to have promising result towards adopting and use of systems for social commerce, social media or ecommerce for that matter[22].

Development and promising progress is not always without a challenge. The Philippines is ranked among countries in the world with the slowest internet connection.

Aside from the fact that the country's internet speed is one of the slowest in the world with the highest price, it is important to take into consideration the following issues and concerns:

Supply Chain and Distribution Management. it is also an archipelagic country that makes logistics more difficult to maintain[23], [24]. Supply chain is particularly difficult in an archipelagic country where typhoons and other natural disaster is a frequent reality. For instance, the Philippines is a country split in two by the most active volcanic ring, the pacific ring of fire. Earthquake is frequent in the country which almost always imposes damage to resources and infrastructures such as roads, bridges, buildings and the like, which could in effect endanger the stability of an ecommerce business which heavily rely on the distributions and delivery.

Natural Disasters. This is closely related with the problems of delivery and distributions of goods ordered online. Natural disasters such as typhoons is very frequent in the Philippines which at some point of the history have rendered the entire Philippine Government inutile, during the devastation of the strongest super typhoon to ever land, HAIYAN with local name Yolanda. In an archipelagic country like the Philippines, typhoons disables all kinds of travel, by sea, land or air, since it is particularly dangerous. Landsides can block roads, wind can topple electric posts or cellular sites, and restrict ships form voyaging the sea. These means mentioned are the primary transport medium to which an ecommerce can thrive.

Political Stability. The Philippine political environment is pretty unstable. Insurgency from leftist groups and extremists sprouts from all over the place. It is primarily true that business relies heavily on stability and peace. When there is a glimpse of terror, business frown and decay.

Poverty. As presented in the introduction of this paper, farmers form part of the most impoverished sectors of the Philippine society. Poverty of the great number is a threat to the stability of any business venture, including ecommerce for that matter. The Philippines statistics authority in 2015 provided that the poverty threshold in the Philippines is at $\mathrm{PhP}$ $9,140.00$. This simply means that $26.1 \%$ of the population lives below poverty line. Farmers, Fishermen and Children remains to be consistent among the poorest sectors in the Philippines society [25].

Technology Availability. Technology have been rapidly changing and controlling the worldwide affairs. However, in third world countries have a fundamental problem with the availability of technology. To the end of the population where basic necessity is given the utmost importance, spending of technology infrastructure is left at lesser priority. The government, though in constant work to keep at par with the standard of technology in the world, the fact still remains that the Philippines is lagging behind in terms of technological advancement. Though, the positive side of this is that, smartphones is widely used among Filipinos with significant penetration rate among millennial.

Technology Awareness. Significant number of Filipinos have smart phones. In fact, mobile 


\begin{tabular}{llllll} 
& ISRA (India) $=\mathbf{3 . 1 1 7}$ & SIS (USA) & $=\mathbf{0 . 9 1 2}$ & ICV (Poland) & $=\mathbf{6 . 6 3 0}$ \\
Impact Factor: & ISI (Dubai, UAE) $=\mathbf{0 . 8 2 9}$ & PUHL (Russia) $=\mathbf{0 . 1 5 6}$ & PIF (India) & $=\mathbf{1 . 9 4 0}$ \\
& GIF (Australia) $=\mathbf{0 . 5 6 4}$ & ESJI (KZ) & $=\mathbf{8 . 7 1 6}$ & IBI (India) & $=\mathbf{4 . 2 6 0}$ \\
& JIF & $\mathbf{1 . 5 0 0}$ & SJIF (Morocco) $=\mathbf{5 . 6 6 7}$ & OAJI (USA) & $\mathbf{0 . 3 5 0}$ \\
\hline
\end{tabular}

subscription in the Philippines exceed beyond the total number of population where unique subscription at 60 Million. While the same is true, the ultimate purpose of using smartphones are limited only for playing games, chatting, and social media and other form of communication. One of the trending activity on smartphones and the internet in the Philippines is online buying through different ecommerce, however, very few have concrete idea the same platform can be used for selling goods. This knowledge insufficiency is particularly prevalent among farmers who either have no proper access to technology or have insufficient knowledge that such platform of technology is available as a tool for improving agriculture business.

Demographic Profile

In the previous discussion, it was established that e-commerce is indeed the way of the future. At this point, we now examine the current status, as to demographic distribution of the small scale farming in Cebu City, and we will try to relate it into the concept of e-commerce.

It is very significant to determine the respondent's age distribution since could be a determinant factor in the production capacity of a farmer. A recent study in China reveals that aging farmers affect the total productivity[26]. The presents the age distribution of the respondents. The data revealed that the highest response in terms of age is from 46-55 years old with the frequency of 45 or $28.8 \%$ of the total respondents. While the lowest frequency is 11 or $7.1 \%$ of the respondents with the ages 66-75 years old.

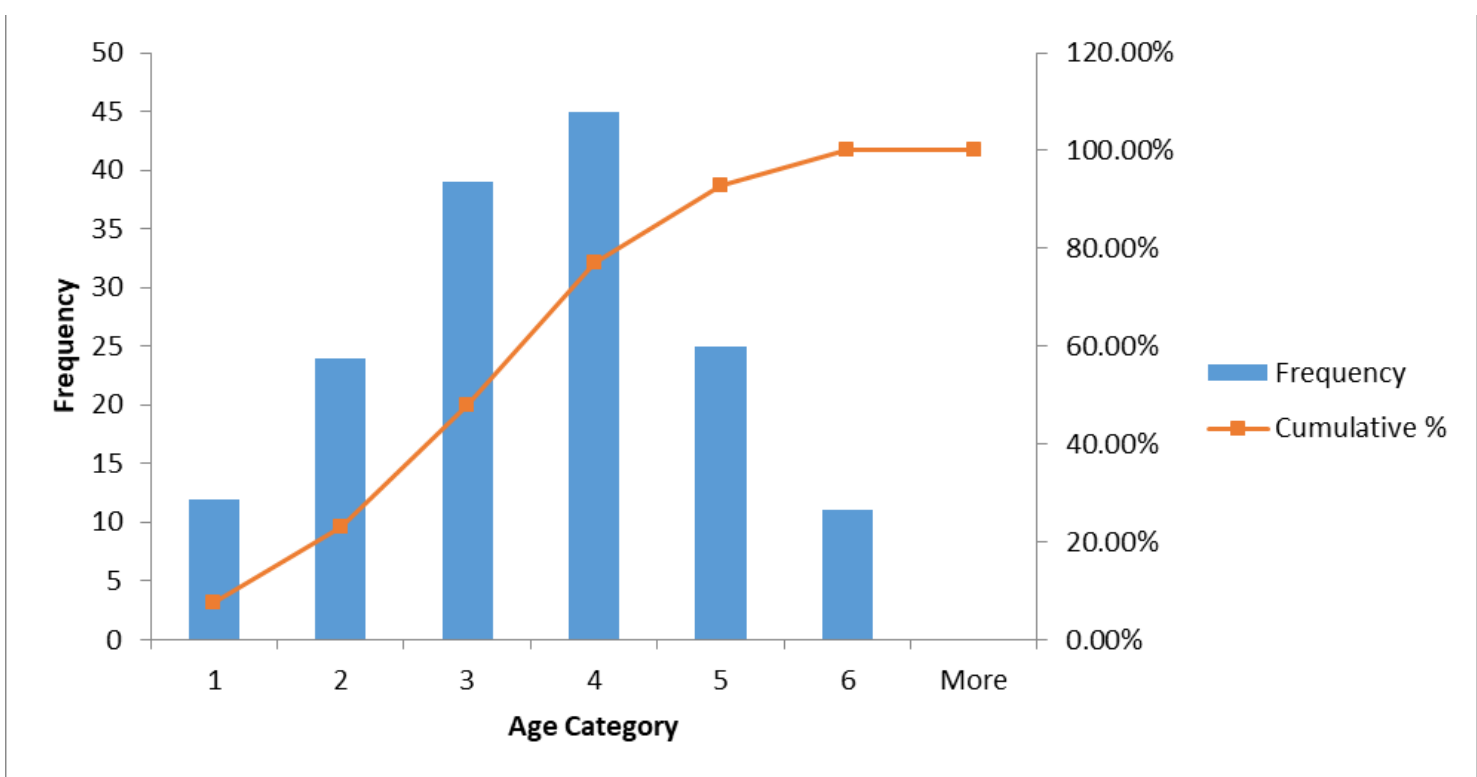

*1. 16-25 years old, 26-35 years old, and so on in 10 intervals

Figure 1. Age Distribution

Based on the data it can be interpreted that farmers are aging and that there is a possibility of shortage of farmers in the next 20 years (Villar, 2018.) This is in congruence with the farmers' census from the Philippine Statistics Authority, which provides that the average age of farmers in the Philippines is in the range of 57-59 years old (PSA, 2016). 


\begin{tabular}{llllll} 
& ISRA (India) $=\mathbf{3 . 1 1 7}$ & SIS (USA) & $=\mathbf{0 . 9 1 2}$ & ICV (Poland) & $=\mathbf{6 . 6 3 0}$ \\
Impact Factor: & ISI (Dubai, UAE) $=\mathbf{0 . 8 2 9}$ & PUHL (Russia) $=\mathbf{0 . 1 5 6}$ & PIF (India) & $=\mathbf{1 . 9 4 0}$ \\
& GIF (Australia) $=\mathbf{0 . 5 6 4}$ & ESJI (KZ) & $=\mathbf{8 . 7 1 6}$ & IBI (India) & $=\mathbf{4 . 2 6 0}$ \\
& JIF & $\mathbf{1 . 5 0 0}$ & SJIF (Morocco) $=\mathbf{5 . 6 6 7}$ & OAJI (USA) & $\mathbf{0 . 3 5 0}$ \\
\hline
\end{tabular}

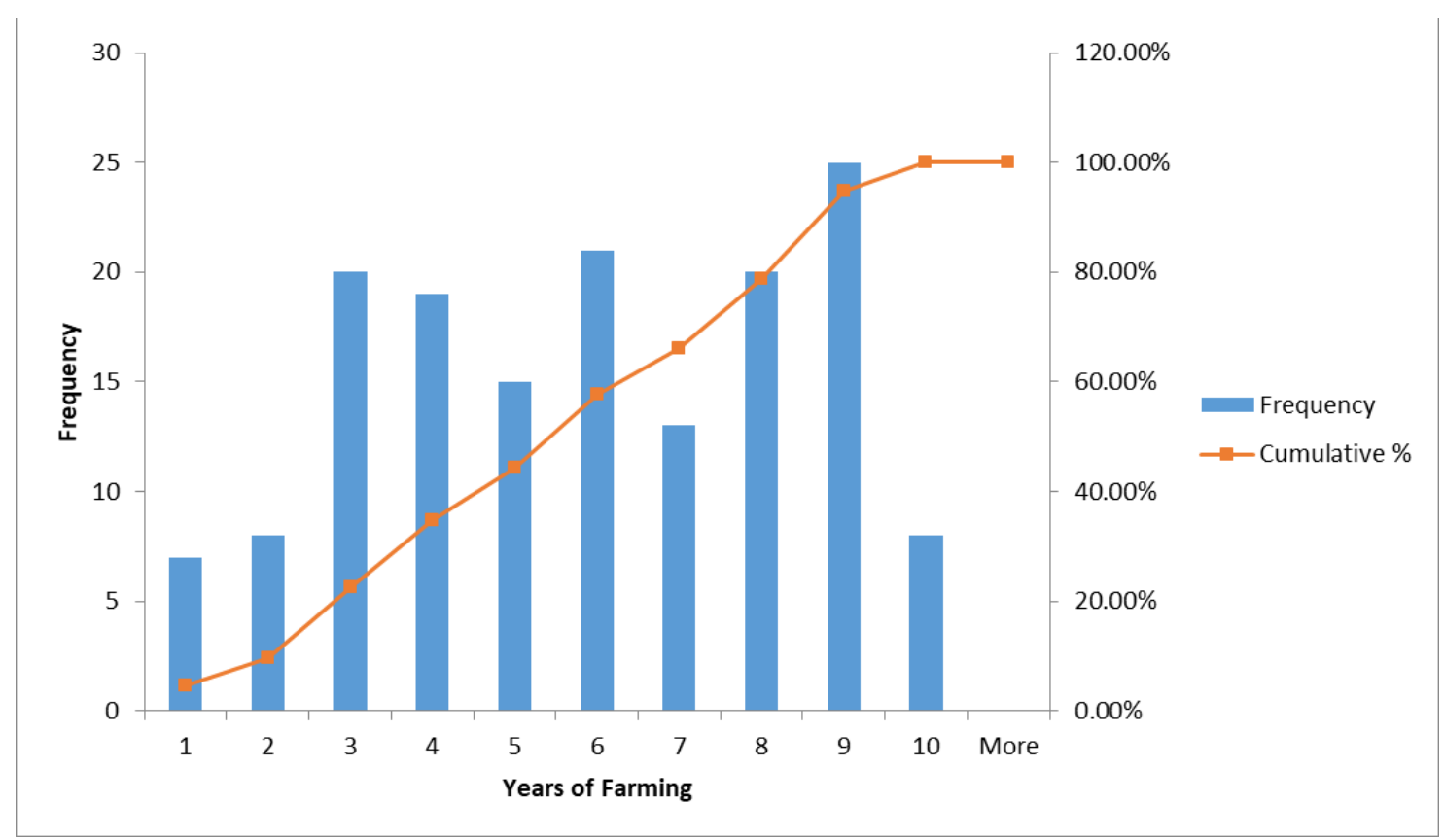

*1. 1-5 years, 2. 6-10 years, and so on in five year interval

Figure 2. Length of Farming Years

As to the length of farming the data revealed the highest number of years in farming is 31-35 years with the frequency of 28 or $17.9 \%$ of the total respondents. To have a clearer view of the frequency distribution by age and the number of farming years. The highest frequency response in each cross-tabulated categories is 12 , the cross-section between $46-55$ years old in the age category and 31-35 years of farming years. It shows the verifiability of the data that displays accuracy in terms of age distribution within this context. The data simply provide support on the national statistics in agriculture regarding the age distribution of farmers in the Philippines (PSA, 2016).

It is important that the farmers are well articulated with the ability to comprehend and understanding of farming instructions given to them by the experts in the field of agriculture. This is because farming is not an easy venture, it requires deeper learning, patience, and precision. With this in mind, the proponent of this research propounded questions on the educational attainment of the farmers in the Cebu City. Based on the data, the highest frequency is 68 or $43.6 \%$ of the respondents are High School Graduate or at least have studied High school. The lowest frequency is 11 or $7.1 \%$ of the total population. Farmers with elementary educations run second in the list with 52 responses or $33.3 \%$ of the total respondents. Lastly, farmers with No Education at all comprise $16 \%$ or 25 responses from the total samples. The data can be interpreted as a very much of a threat to productivity. The lower the educational attainment of farmers the lower the productivity. Based on the study published in the American Journal of Agricultural Economics (AJAE) it was found out that that education will have larger impacts on agricultural productivity in the presence of rapid technical change since it helps farmers to adjust more readily to the new opportunities provided by technological innovations (Klasen and Reimers, 2011). 


\begin{tabular}{llllll} 
& ISRA (India) $=\mathbf{3 . 1 1 7}$ & SIS (USA) & $=\mathbf{0 . 9 1 2}$ & ICV (Poland) & $=\mathbf{6 . 6 3 0}$ \\
Impact Factor: & ISI (Dubai, UAE) $=\mathbf{0 . 8 2 9}$ & PUHL (Russia) $=\mathbf{0 . 1 5 6}$ & PIF (India) & $=\mathbf{1 . 9 4 0}$ \\
& GIF (Australia) $=\mathbf{0 . 5 6 4}$ & ESJI (KZ) & $=\mathbf{8 . 7 1 6}$ & IBI (India) & $=\mathbf{4 . 2 6 0}$ \\
& JIF & $\mathbf{1 . 5 0 0}$ & SJIF (Morocco) $=\mathbf{5 . 6 6 7}$ & OAJI (USA) & $\mathbf{0 . 3 5 0}$ \\
\hline
\end{tabular}

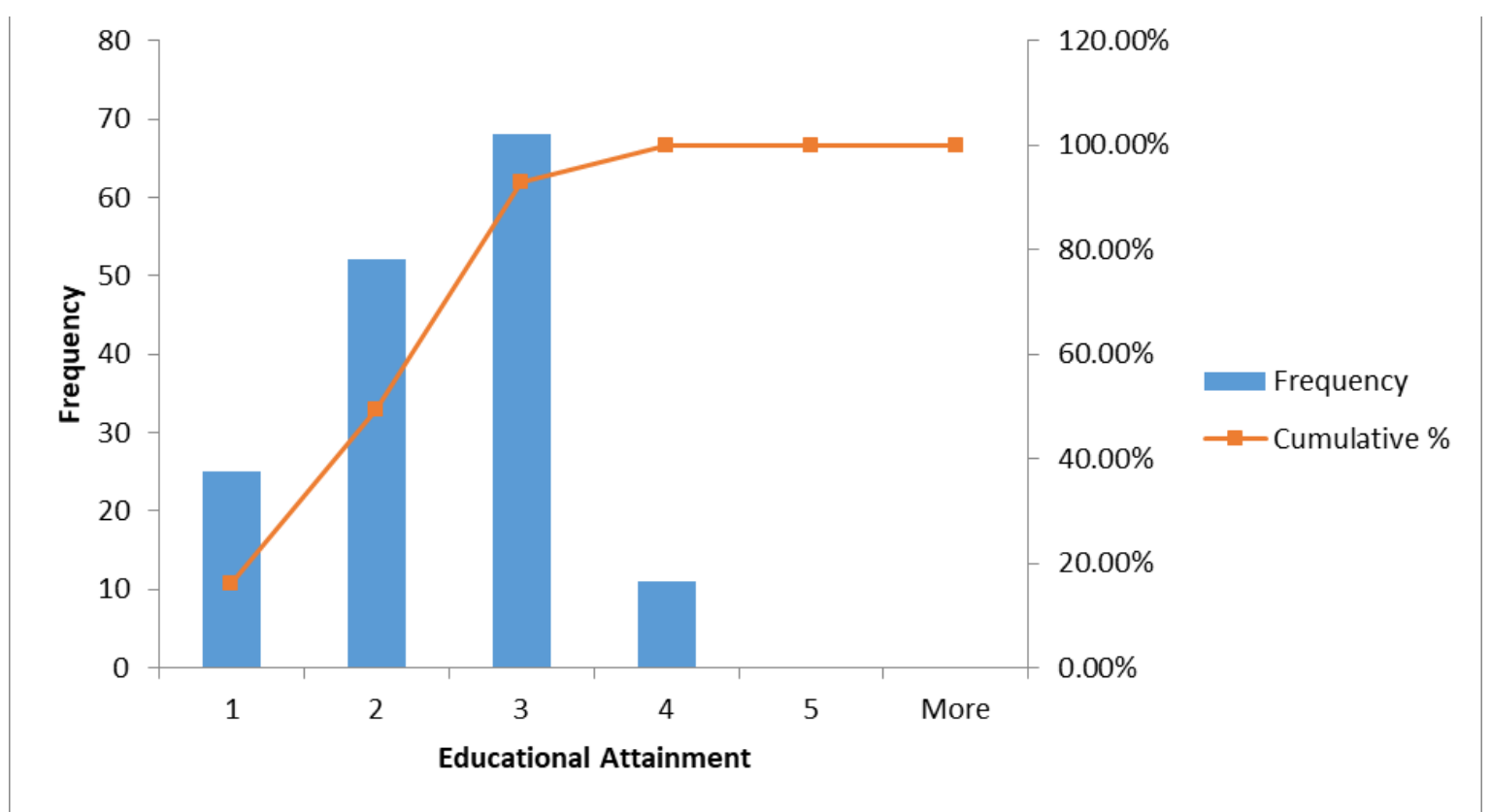

*1. No Educaction, 2. Elementary, 3. High School, 4. College

Figure 3. Educational Attainment

\section{Awareness on Ecommerce Platforms}

While the world is rapidly advancing to the cyber world where everything is available on the internet, accessible through the touch of a button or a tap in the mobile phone. It is significant to determine whether or not the farmers are aware of the present advancement of marketing technology. That, any person can communicate through the internet and sell products from it. Table 5 shows the relevant level of awareness of the farmers in terms of social media marketing technology.

Table 1. E-Commerce Platforms

\begin{tabular}{l|r|r|l}
\hline & Mean & $\begin{array}{c}\text { Std. } \\
\text { Deviation }\end{array}$ & Interpretation \\
\hline Facebook Marketplace & 2.89 & 1.633 & Somewhat Aware \\
\hline Lazada & 2.17 & 1.464 & Slightly Aware \\
\hline Shopee & 1.99 & 1.191 & Slightly Aware \\
Olx & 1.81 & 1.106 & Slightly Aware \\
Shopify & 1.59 & 0.922 & Not Aware \\
Youtube & 1.61 & 0.989 & Not Aware \\
\hline & 2.01 & \multicolumn{2}{|l}{ Slightly Aware } \\
\hline
\end{tabular}

Table 1 presents the respondent's responses to the propounded questions of e-commerce platform technology awareness. Facebook is considered to be the most well know platform in the social media with the mean of 2.89 which can be interpreted by the use of the scoring procedure as slightly aware. This means that the farmers know a little about Facebook Marketplace but not using it as a tool for selling. The list is followed by Lazada, Shopee, Olx with means,
2.17, 1.99 and 1.81 which can be interpreted as Slightly Aware, respectively. Shopify and YouTube, is considered to be the most unpopular means of selling online with means 1.59 and 1.61 which can be interpreted as Not Aware. The respondent farmers does not have an idea that the said platforms can be a vehicle for selling goods and services.

Little or no awareness of the e-commerce and social media platforms could mean a great loss for the 


\begin{tabular}{llllll} 
& ISRA (India) $=\mathbf{3 . 1 1 7}$ & SIS (USA) $=\mathbf{0 . 9 1 2}$ & ICV (Poland) & $\mathbf{= 6 . 6 3 0}$ \\
Impact Factor: & ISI (Dubai, UAE) $=\mathbf{0 . 8 2 9}$ & PUHЦ (Russia) $=\mathbf{0 . 1 5 6}$ & PIF (India) & $=\mathbf{1 . 9 4 0}$ \\
& GIF (Australia) $=\mathbf{0 . 5 6 4}$ & ESJI (KZ) & $\mathbf{8 . 7 1 6}$ & IBI (India) & $=\mathbf{4 . 2 6 0}$ \\
& JIF & $\mathbf{1 . 5 0 0}$ & SJIF (Morocco) $=\mathbf{5 . 6 6 7}$ & OAJI (USA) & $\mathbf{0 . 3 5 0}$ \\
\hline
\end{tabular}

farmers, this is in consideration of the fact that the same platform is a means of which the modern day commerce in exchanging products or services. Modernity is anchored through the internet. Today's consumer demands a seamless online journey across the various digital platforms. Hence it is crucial for them to make the customers' journey easy and painfree so that customers do not disengage from the process and go elsewhere (https://goo.gl/LQ3Y8X).

\section{Income}

The total volume of the product among the 156 respondents of the study is 277, 363 kilograms of high-value crops. The productivity level was measured in 3 months to determine the accuracy of harvest variation per item. The total revenue of the farmers is PHP. 8,857,700.00. The average revenue per farmer in three months is PHP. 56,780.12.

The total per month revenue is PHP. 18, 926.00 per farmer. To get the net income per month, the total revenue will be deducted a total of $60 \%$ as farm capitalization or cost. The farm capitalization per farmer is PHP. 11,356.02. The net income per month of a farmer in the City of Cebu is PHP. 7,570.68.

\footnotetext{
$I=(((P 1 * \operatorname{Pr} 1+\operatorname{P} 2 * \operatorname{Pr} 2 \ldots) / 3)-((P 1 * \operatorname{Pr} 1+$ $P 2 * \operatorname{Pr} 2 \ldots) / 3) * 6) / 5$

$I=$ individual income per month

$P=$ Farm Product Produced

Pr $=$ Price Per Product Produced

$3=i s$ a constant, which refers to the three months

$60 \%=$ is a defined constant based on the City Agriculture department, approximated total investment per crop.
}

$5=i$ a constant, referring to the typical number per family in the City of Cebu.

With a family of five, the income of farmers in the City of Cebu is way beyond the poverty line. The data reveals that the average allowable consumption for every family member in a month is only Php. 1,514.13. Which means that indeed, the Philippines Statistics Authority is correct in pointing out that farmers is the poorest sector in the Philippines. In 2015 , the income required for a family of five is at least PhP 9,140.00 to meet the basic food and nonfood needs (PSA, 2015).

\section{Correlation to Income}

Using correlation method through the use of Statistical Software such as Microsoft Excel, based on the 156 samples, the data revealed, that as of the present status of technology awareness and use, there is no significant statistical correlation between awareness and use of e-commerce and social media to income among small-scale farmers at p-value of 0.074. Though, it can be observed from the data that there was inclination towards positive correlation, it is still not within the standard significance level. This simply means that at the present status of technology and awareness among small scale farmers, there is found no significant impact on income. In the simplest term, by statistical standard, the awareness and use of social media doesn't have enough evidence to have an impact on income among small-scale farmers in Cebu City, Philippines.

Table 2. Profile and Income

\begin{tabular}{|lc|l|}
\hline \multicolumn{2}{|c|}{ INCOME } \\
\hline & $\mathrm{p}$-value & \multicolumn{1}{c|}{ Interpretation } \\
\hline e-Commerce Awareness & 0.074 & There is no significant correlation \\
\hline Age & 0.015 & There is significant correlation \\
\hline No of Farming Years & 0.034 & There is significant correlation \\
\hline Educational Attainment & 0.149 & There is no significant correlation \\
\hline${ }^{*}$ Correlation significant at $\alpha=0.05$ &
\end{tabular}

The data also reveals that, Educational Attainment does not have any correlation with income, at p-value of 0.149 . This means that there is not enough evidence that education have direct or indirect effect on the farmers' income. Moreover, there is statistical correlation between the number of years on farming at p-value of .034, and Age, with the $\mathrm{p}$-value of .015. This means that there is enough evidence that Age and the length of farming have an effect on the income of farmers. This is in consonance to the observable fact within the society that indeed, age can be a determining factor towards higher income. The positive correlation between age and income however is not a new discovery, since enumerable studies shows the same results.

\section{Implications}

The empowerment arising from technological advancement is beyond question in all fields of endeavor. Poverty as a perennial horror continues to 


\begin{tabular}{llllll} 
& ISRA (India) $=\mathbf{3 . 1 1 7}$ & SIS (USA) $=\mathbf{0 . 9 1 2}$ & ICV (Poland) & $\mathbf{= 6 . 6 3 0}$ \\
Impact Factor: & ISI (Dubai, UAE) $=\mathbf{0 . 8 2 9}$ & PUHЦ (Russia) $=\mathbf{0 . 1 5 6}$ & PIF (India) & $=\mathbf{1 . 9 4 0}$ \\
& GIF (Australia) $=\mathbf{0 . 5 6 4}$ & ESJI (KZ) & $\mathbf{8 . 7 1 6}$ & IBI (India) & $=\mathbf{4 . 2 6 0}$ \\
& JIF & $\mathbf{1 . 5 0 0}$ & SJIF (Morocco) $=\mathbf{5 . 6 6 7}$ & OAJI (USA) & $\mathbf{0 . 3 5 0}$ \\
\hline
\end{tabular}

batter the third world, in which technology has to play a very important role to subdue its horrific impact. The governments in the world, not only in the Philippines have to formulate strategic platforms, Public Private Partnerships and government funded programs to solidify the communication infrastructures and induce public education on the availability of technology that allows small-scale business including farmers to sell its goods through the world wide web. Through the development of the communication infrastructure, more will be able to access the web at the lower cost, thereby augmenting the potential it can offer to the smallest member of the society.

The Department of Agriculture in the Philippines, together with other government agencies have to formulate plans that empowers the small scale farmers at the bottom, use of technology for the marketing of farm produce. Concerned agencies have to establish an implementation and monitoring panel that ensures proper aid for the empowerment of farmers that works so hard somewhere in the islands of the Philippine Archipelago.

\section{CONCLUSION}

The requisite of development in the modern world is to adapt on whatever technological advancement it offers. In this case, farmers, with the aid of concerned state agencies have to acquire knowledge on the use of technology in modern commerce. Market demands widens as cyber world expands. To cater such demands, farmers must be brought to the internet, with the advent of e-commerce platforms, farmers can sell to anyone from anywhere.

\section{References:}

1. Moavenzadeh, J. (n.d.). The 4 th Industrial Revolution: Reshaping the Future of Production.

2. Tien, J. M. (2012, Sept.). The next industrial revolution: Integrated services and goods," $J$. Syst. Sci. Syst. Eng., vol. 21, no. 3, pp. 257-296.

3. Eid, R., \& El-Gohary, H. (2013, Jan.). The impact of E-marketing use on small business enterprises' marketing success. Serv. Ind. J., vol. 33, no. 1, pp. 31-50.

4. Tsiotsou, R. H., \& Vlachopoulou, M. (2011, March). Understanding the effects of market orientation and e-marketing on service performance. Mark. Intell. Plan., vol. 29, no. 2, pp. 141-155.

5. Cheung, C. M., \& Thadani, D. R. (2010). The Effectiveness of Electronic Word-of-Mouth Communication: A Literature Analysis.

6. Chaib-draa, B., \& Müller, J. P. (2006). Multiagent based supply chain management. Springer-Verlag.

7. Matsuo, T., \& Colomo-Palacios, R. (2013). Towards New Generation E-Business and Marketing, pp. 1-3.

8. El-Gohary, H. (2010). E-Marketing-A literature Review from a Small Businesses perspective.

9. Gangeshwer, D. K. (2013). E-Commerce or Internet Marketing: A Business Review from Indian Context. Int. J. u-and e-Service, vol. 6, no. 6, pp. 187-194.

10. Leung, X. Y., Bai, B., \& Stahura, K. A. (2015, May). The Marketing Effectiveness of Social
Media in the Hotel Industry. J. Hosp. Tour. Res., vol. 39, no. 2, pp. 147-169.

11. (2017). PSA, Farmers, Fishermen and Children consistently posted the highest poverty incidence among basic sectors - PSA | Philippine Statistics Authority. Retrieved Nov.16, 2018, from https://psa.gov.ph/content/farmers-fishermenand-children-consistently-posted-highestpoverty-incidence-among-basic

12. Briones, R. M. (2015, Aug.). "Small Farmers in High-Value Chains: Binding or Relaxing Constraints to Inclusive Growth?" World Dev., vol. 72, pp. 43-52.

13. Wen, W. (2010). "Agricultural e-commerce application mode in China," in 2010 2nd IEEE International Conference on Information Management and Engineering, pp. 616-619.

14. Jamaluddin, N. (2013, Jan.). "Adoption of Ecommerce Practices among the Indian Farmers, a Survey of Trichy District in the State of Tamilnadu, India," Procedia Econ. Financ., vol. 7, pp. 140-149.

15. Martinez, C. P., Castaneda, M. G., Marte, R. B., \& Roxas, B. (2015, Nov). "Effects of institutions on ecological attitudes and behaviour of consumers in a developing Asian country: the case of the Philippines," Int. J. Consum. Stud., vol. 39, no. 6, pp. 575-585.

16. (2018). Department of Trade and Industries, "ECommerce," Retrieved Feb.12, 2019, from 


\begin{tabular}{llllll} 
& ISRA (India) $=\mathbf{3 . 1 1 7}$ & SIS (USA) & $=\mathbf{0 . 9 1 2}$ & ICV (Poland) & $=\mathbf{6 . 6 3 0}$ \\
Impact Factor: & ISI (Dubai, UAE) $=\mathbf{0 . 8 2 9}$ & PUHL (Russia) $=\mathbf{0 . 1 5 6}$ & PIF (India) & $=\mathbf{1 . 9 4 0}$ \\
& GIF (Australia) $=\mathbf{0 . 5 6 4}$ & ESJI (KZ) & $=\mathbf{8 . 7 1 6}$ & IBI (India) & $=\mathbf{4 . 2 6 0}$ \\
& JIF & $\mathbf{1 . 5 0 0}$ & SJIF (Morocco) $=\mathbf{5 . 6 6 7}$ & OAJI (USA) & $\mathbf{0 . 3 5 0}$ \\
\hline
\end{tabular}

https://www.dti.gov.ph/ecommerce/84-maincontent/eco-news

17. (2015). Demandware and Singapore, "Developing eCommerce Market Entry Strategies in Asia-Pacific - Advisory Report 2015. Google Search". Retrieved Feb.12, 2019, from

http://www.specommerce.com.s3.amazonaws.c om/dl/wp/SingPost-eCommerce-DemandwareAdvisory-Report-2015.pdf

18. (2018). We Are Social, "Digital in 2018 in Southeast Asia Part 2 - South-East". Retrieved Feb.12, 2019, from https://www.slideshare.net/wearesocial/digitalin-2018-in-southeast-asia-part-2-southeast86866464

19. (2018). Rappler and GLOBE, "A profile of Internet users in the Philippines". Retrieved Feb.12, 2019, from https://www.rappler.com/brandrap/profileinternet-users-ph

20. (2010). "R.A. 10175". Retrieved Feb.12, 2019 , from https://www.lawphil.net/statutes/repacts/ra2012 /ra_10175_2012.html

21. (2015). "Transparency Seal | Free Public Wi-Fi”. Retrieved Feb.12, 2019, from http://freepublicwifi.gov.ph/transparency-seal/
22. Lewis, K. P., Luis, M., Santos, C. D., \& Gonzales, D. B. (2018). "Social Commerce Acceptance of Students in a State University in the Philippines: A Unified View," Circ. Comput. Sci., vol. 3, no. 3 .

23. Tan, J., \& Indramawan, A. (2018). Probing into e-commerce logistics: a strategic growth option of serbada company.

24. Tongzon, J. L. (2018). Regulatory challenges in the Philippine logistics industry. Philippine Institute for Development Studies.

25. (2017). PSA, "Philippine Statistics Authority | Republic of the Philippines". Retrieved Apr.11, 2019, from https://psa.gov.ph/poverty-pressreleases/nid/120251

26. Guo, G., Wen, Q., \& Zhu, J. (2015, Oct.). “The Impact of Aging Agricultural Labor Population on Farmland Output: From the Perspective of Farmer Preferences," Math. Probl. Eng., vol. 2015, pp. 1-7.

27. Villar, M. B. (2017). "Of aging farmers and food security | BusinessMirror." Retrieved Feb.04, 2019, from https://businessmirror.com.ph/2017/03/06/ofaging-farmers-and-food-security/ 